\title{
Growth, crown architecture and leaf dynamics of saplings of five mangrove tree species in Ranong, Thailand
}

\author{
Nobuo Imai ${ }^{1, *}$, Masaaki Takyu $^{2}$, Yukito Nakamura ${ }^{2}$ \\ ${ }^{1}$ Center for Ecological Research, Kyoto University, Hirano 2-509-3, Ohtsu, Shiga 520-2113, Japan \\ ${ }^{2}$ Department of Forest Science, Faculty of Regional Environmental Science, Tokyo University of Agriculture, \\ Sakuragaoka 1-1-1, Setagaya, Tokyo 156-8502, Japan
}

\begin{abstract}
We investigated the regeneration pattern of mangrove forests, considering the correspondence between growth strategies (i.e. sapling growth, crown architecture, leaf dynamics) of 5 canopy-dominant species and the disturbance regime in Ranong, Thailand. Individual canopy gap size and percent gap area were greater in the Sonneratia alba-Avicennia alba (SA) zone, which is located on the most seaward fringe, than in the other inland zones. In canopy gaps, the seaward species $S$. alba and $A$. alba showed a higher relative height growth rate than the inland species Rhizophora apiculata, Bruguiera gymnorhiza and Xylocarpus granatum. Under closed canopies, the seaward species showed greater mortality, presumably due to their low shade tolerance, while the inland species demonstrated a net growth in spite of the dark conditions. Leaf longevity of sunlit saplings increased from seaward to inland species. The 2 seaward species had well-branched, slender and deeper crowns, while $R$. apiculata and B. gymnorhiza had wider and flatter crowns, and $X$. granatum had less-branched, smaller crowns. Phenotypic traits were correlated with each species' growth strategy (potential growth rate and shade tolerance), which corresponded to the disturbance regime in each vegetation zone. Many large gaps may enhance the abundance of $S$. alba and $A$. alba in the SA zone, and a few small gaps may prevent establishment and growth of light-demanding species in the inland zones. Accordingly, the correspondence of disturbance regime and growth strategies of canopy-dominant species provides an advantage for successful regeneration, and may contribute to the maintenance of the present species composition in each vegetation zone.
\end{abstract}

KEY WORDS: Crown architecture - Leaf longevity · Biomass allocation · Leaf morphology · Regeneration $\cdot$ Disturbance regime $\cdot$ Mangrove $\cdot$ Zonation

\section{INTRODUCTION}

Mangroves are intertidal forests that dominate tropical and subtropical regions. In mangrove forests, small canopy gaps are created by various natural disturbances (e.g. hurricanes, cyclones, lightning, herbivory and disease) or by anthropogenic deforestation (Jiménez et al. 1985, Smith et al. 1994, Feller \& McKee 1999, Sherman et al. 2000, 2001, Allen et al. 2001, Pinzón et al. 2003). These canopy gaps promote the establishment and growth of mangrove saplings through the creation of brighter conditions (Rabinowitz 1978, Smith
1987, Tamai \& Iampa 1988, Ellison \& Farnsworth 1993, Pinzón et al. 2003). Responses of tree species to changes in light conditions are known to differ among species (Tamai \& Iampa 1988, McKee 1995, Sherman et al. 2000, Pinzón et al. 2003, Clarke 2004). The relationship between species-specific growth rate and the spatiotemporal pattern of patches with different light intensity in the forest determines the success of saplings in completing their life cycles, which in turn determines the population dynamics of a mangrove forest.

The amount of cumulative light per leaf and life span of leaves determine the overall primary production. 
The amount of cumulative light depends on the form and branching of a canopy. Generally, saplings of light-demanding species display leaves with a lessbranched, narrow crown supported by a slender trunk; in contrast, saplings of shade-tolerant species have a well-branched, wide crown on a thick trunk. A narrow crown could be advantageous for rapid growth in height within gaps due to its large leaf area density with less supporting tissue, whereas a wide crown may be able to intercept light effectively without self-shading under a closed canopy (Takahashi et al. 2001). This structural trade-off is now known to be tightly correlated with potential growth rate and shade tolerance (i.e. the ability to survive under dark conditions) (Takahashi et al. 2001, Takahashi \& Rustandi 2006). Furthermore, the individual-level potential growth rate is known to be correlated with traits of leaf dynamics. Light-demanding species often have shown shorter leaf longevity, which enables them to exhibit a higher photosynthetic rate than shadetolerant species (Shukla \& Ramakrishanan 1984, Reich et al. 1992, Gower et al. 1993, Navas et al. 2003, Poorter \& Bongers 2006).

However, interspecific differences in potential growth rate and shade tolerance in reference to morphological and phenological traits of saplings are poorly understood in mangrove forests. For a few species, sapling architecture and allometry has been studied in either gaps or closed canopies (Turner et al. 1995). Plasticity of leaf and crown morphology across changing light conditions has been documented only for Rhizophora mangle (Farnsworth \& Ellison 1996). Quantitative measurements of crown architecture among species growing under both gaps and closed canopies are still lacking, and there are no descriptions of leaf longevity in saplings of mangrove species.

The objective of the present study was to compare the responses of growth rate, crown architecture and leaf longevity to changing light conditions (i.e. closed canopies versus gaps) among saplings of 5 mangrove tree species in Ranong, Thailand: Sonneratia alba, Avicennia alba, Rhizophora apiculata, Bruguiera gymnorhiza and Xylocarpus granatum. Mangrove vegetation is characterized by distinct zonation patterns of constituent species across an intertidal gradient. In southern Thailand, forests change from an S. alba and A. alba mixed forest at the seaward fringe to an $R$. apiculata-dominant forest just inland, then to an R. apiculata and B. gymnorhiza mixed forest, and finally to a forest dominated by XYlocarpus spp. (X. granatum and $X$. moluccensis) at the point furthest inland (Miyawaki et al. 1985, Mochida et al. 1999, Imai et al. 2006). Since species diversity in each zone is very low, a clear understanding of the sapling performance of canopy-dominant species in each vegetation zone is crucial for a comprehensive understanding of mangrove forest dynamics. Our goal was to reveal the regeneration pattern of mangrove forests, considering the correspondence between the growth strategies of canopy-dominant species and the disturbance regimes in each vegetation zone studied by Imai et al. (2006). Gap characteristics and forest structure differ among the 4 zones in mangrove forests in Ranong (Imai et al. 2006). We hypothesized that growth rate and morphological and phenological traits of mangrove species are related to the light conditions where they dominate. Species that grow in the forests with large gaps were expected to have higher growth rates, shorter leaf longevity, lower mass per unit height, and a less-branched narrow crown than species that grow in forests with small gaps, which were expected to show the opposite pattern.

\section{MATERIALS AND METHODS}

Study site. The present study was carried out in tropical mangrove forests located in the Ranong Biosphere Reserve in southwestern Thailand ( $\left.9^{\circ} 50^{\prime} \mathrm{N}, 98^{\circ} 35^{\prime} \mathrm{E}\right)$. Ranong is the rainiest region in Thailand; mean annual rainfall is $4200 \mathrm{~mm}$ with 190 rainy days per year on average. This area has a dry season from October to March. Mean annual temperature is $26.7^{\circ} \mathrm{C}$. The tidal regime at Ranong is predominantly semi-diurnal with a mean range of $2.4 \mathrm{~m}$ and an annual maximum of $4.4 \mathrm{~m}$ (Macintosh et al. 1991).

The Ranong Mangrove Forest Research Center (RMFRC) has preserved the mangrove forests within the Ranong Biosphere Reserve. Four zones or communities typical of this region occur along a seaward to inland intertidal gradient: (1) Sonneratia alba-Avicennia alba, (2) Rhizophora apiculata, (3) R. apiculataBruguiera gymnorhiza, and (4) Ceriops tagal-Xylocarpus spp. (Mochida et al. 1999).

To compare the species composition, forest structure and disturbance regime among the zones, Imai et al. (2006) established 6 study plots in the 4 vegetation zones from August 2003 to October 2004. Two study plots in the Sonneratia alba-Avicennia alba forest (SA zone), SA-1 $\left(6300 \mathrm{~m}^{2}\right)$ and SA-2 $\left(4500 \mathrm{~m}^{2}\right)$, were established at the seaward fringe. In the Rhizophora apiculata forest (Ra zone), located about $200 \mathrm{~m}$ inland from the seaward fringe, 2 study plots, Ra-1 $\left(4800 \mathrm{~m}^{2}\right)$ and Ra-2 $\left(3600 \mathrm{~m}^{2}\right)$, were established. One plot $\left(6000 \mathrm{~m}^{2}\right)$ was set up in the $R$. apiculata-Bruguiera gymnorhiza forest (RB zone) located about $100 \mathrm{~m}$ inland from Ra-1, and one plot $\left(4800 \mathrm{~m}^{2}\right)$ was established in the Ceriops tagalXylocarpus spp. forest (CX zone), the most inland zone.

Light conditions. Saplings of each of the 5 dominant species were chosen in the zone where each species was dominant. In July 2004, 13 to 24 undamaged saplings of each species were selected within gaps and 13 to 26 undamaged saplings of each species were selected under closed canopies. Sapling height ranged from 50 to 
$250 \mathrm{~cm}$. To understand the difference in the light conditions between gaps and closed canopies, hemispherical fish-eye photographs were taken above the apex of each sapling. The photographs were taken under an overcast sky with a Coolpix 5400 digital camera equipped with a FC-E9 fish-eye converter (Nikon). Images were processed using LIA32 image analysis software (version $0.376 \beta 1$, K. Yamamoto), which allowed determination of the indirect site factor (ISF), direct site factor (DSF) and total site factor (TSF). ISF, DSF and TSF are the fractions of indirect, direct and total potential daily photosynthetic photon flux density (PPFD) that penetrate to a particular site relative to the amount of radiation above the forest canopy. TSF, which represents the proportion of total above-canopy PPFD that is received above the apex of a sapling, was used to compare the light conditions between gaps and closed canopies.

Crown and leaf morphology. Sapling height, crown area and crown depth were measured for selected saplings. Crown projection area was defined as an ellipse form. Crown depth was defined as the difference between tree height and the lowest branching height. At each of 3 different vertical positions in a crown (upper, intermediate and lower), 3 lateral branches were selected randomly (a total of 9 branches) and branch length and number of leaves were measured. At least 5 fully mature leaves per sapling were sampled, scanned by an image scanner and measured for leaf area using LIA32. Total leaf area per tree was estimated by multiplying the total number of leaves by the mean leaf area. Tree leaf area index (tree LAI) was defined as the total leaf area per tree divided by its crown projection area. Total branch length was estimated by multiplying the total number of lateral branches by the mean lateral branch length. Leafiness was defined as the total leaf area per tree divided by total shoot length (sapling height plus total branch length). After the measurements of leaf morphology, leaves were dried at $70^{\circ} \mathrm{C}$ for $72 \mathrm{~h}$ for calculation of specific leaf area (SLA). Species with low SLA typically have a thicker leaf blade or denser tissue, or both (Witkowski \& Lamont 1991).

In September 2005, 4 to 5 saplings 55 to $250 \mathrm{~cm}$ in height were chosen in both gaps and closed canopies to evaluate the biomass allocation pattern. Saplings were harvested and weighed to determine the dry mass for each organ (leaf, stem and branch) after drying at $70^{\circ} \mathrm{C}$ for $4 \mathrm{~d}$.

Leaf dynamics. Leaf longevity was measured for the 5 mangrove species in both gaps and closed canopies. However, saplings of Sonneratia alba and Avicennia alba showed a high mortality rate and a high percentage of loss of lateral branches 3 mo after the beginning of the census under closed canopies; mortality rate was 38 and $19 \%$, and the percentage of loss of lateral branches was 5 and $29 \%$ in $S$. alba and A. alba, res- pectively. Therefore, estimation of leaf longevity could not be conducted for their shade saplings (closed canopies). For 6 to 11 sun saplings (gaps) of all 5 species and 9 to 14 shade saplings of each of the 3 inland species, the number and position of missing and newly emerged leaves were recorded at 3 to 4 mo intervals from July 2004 to September 2005. The mean leaf production rate and loss rate (no. per year per shoot) were expressed as the percentage of leaves produced or shed per year relative to the total number of leaves present at the beginning of the study. Leaf longevity was calculated from the total number of leaves on marked shoots at the beginning of the study divided by the mean of leaf production rate and leaf loss rate (Ochieng \& Erftemeijer 2002).

Relative height growth rate. Tree height was remeasured in September 2005 to allow the estimation of relative height growth rate (RHGR):

$$
\text { RHGR }=\left(H_{t}-H_{0}\right) H_{0}^{-1} t^{-1}
$$

where $H_{t}$ is tree height after $t$ years and $H_{0}$ is tree height at the beginning of the study. Estimation of RHGR for Sonneratia alba and Avicennia alba shade saplings could not be conducted due to high mortality.

Data analyses. ANOVA was used to compare the light conditions, RHGR, leaf morphology and dynamics among species. When the ANOVA p-value was $<0.05$, the Tukey-Kramer post hoc test was performed to determine which pairs of means differed significantly. Comparison of these attributes between gaps and closed canopies in each species were tested by the Student's $t$-test. Differences in the slopes and intercepts of the regression lines between crown architectural attributes (stem mass, crown area, crown depth, total branch length, total leaf area, leafiness and tree LAI) and sapling height as a covariate were tested by analysis of covariance-like comparisons using SMATR software (version 2; Falster et al. 2006).

\section{RESULTS}

\section{Light environment}

The TSF above saplings was significantly greater in gaps than in closed canopies in all species $(p<0.001)$ (Table 1). However, TSF values differed among species. Values in gaps were greater in the 2 seaward species (Sonneratia alba and Avicennia alba) than in the 3 inland species (Rhizophora apiculata, Bruguiera gymnorhiza and Xylocarpus granatum) because the SA zone had substantially larger gaps than the 3 inland zones ( $R a, R B$, and CX zones) (Imai et al. 2006). The TSF in closed canopies showed a similar pattern to that shown in gaps, because tree LAI in the SA zone was smaller than in the other 3 zones (N. Imai et al. unpubl. data). 
Table 1. Comparisons of total site factor (TSF) of saplings of 5 mangrove species in gaps and closed canopies. Species sharing the same letters did not differ significantly at $\mathrm{p}<0.05$. Comparison of means between gaps and closed canopies: ${ }^{* * *} p<0.001$

\begin{tabular}{|lrrrrr|}
\hline & \multicolumn{3}{c}{ Gap } & \multicolumn{3}{c|}{ Closed } & \\
& Mean & SD & Mean & SD & p \\
\hline Sonneratia alba & $93.5^{\mathrm{a}}$ & 5.6 & $37.3^{\mathrm{a}}$ & $8.2^{* * *}$ & ${ }^{* * *}$ \\
Avicennia alba & $87.9^{\mathrm{a}}$ & 5.0 & $36.6^{\mathrm{ab}}$ & $8.4^{* * *}$ \\
Rhizophora apiculata & $46.5^{\mathrm{b}}$ & 10.5 & $32.0^{\mathrm{ab}}$ & $4.6^{* * *}$ & ${ }^{* * *}$ \\
Bruguiera gymnorhiza & $38.7^{\mathrm{b}}$ & 8.2 & $29.0^{\mathrm{b}}$ & $6.5^{* * *}$ & ${ }^{* * *}$ \\
Xylocarpus granatum & $46.4^{\mathrm{b}}$ & 12.1 & $29.3^{\mathrm{b}}$ & $5.3^{* * *}$ \\
\hline
\end{tabular}

\section{Relative height growth rate}

The RHGR of sun saplings differed in the order Sonneratia alba $>$ Avicennia alba $\geq$ Rhizophora apiculata $=$ Bruguiera gymnorhiza $\geq$ Xylocarpus granatum (Fig. 1). Under closed canopies, because $S$. alba and A. alba showed a high mortality rate, RHGR of these 2 species could not be estimated. Shade saplings showed a lower RHGR than sun saplings for the 2 rhizophoraceous species R. apiculata and B. gymnorhiza, but did not differ significantly in $X$. granatum. The RHGR of shade saplings did not differ among $R$. apiculata, B. gymnorhiza and $X$. granatum.

\section{Biomass allocation and crown architecture}

In gaps, stem mass was lowest in Xylocarpus granatum among the 5 species at a comparable tree height, but did not differ among the other 4 species (Table 2, Fig. 2a). Stem mass of $X$. granatum was also lowest under closed canopies (Fig. 2b).

In both gaps and closed canopies among trees of comparable height, crown area was lowest in Xylocarpus granatum, intermediate in Sonneratia alba and Avicennia alba, and highest in Rhizophora apiculata and Bruguiera gymnorhiza (Fig. 3a). Crown depth of the 2 seaward species was significantly larger than the other 3 inland species under closed canopies (Fig. 3b); A. alba and the 2 rhizophoraceous species did not differ in slope of the regression lines but differed in intercept. Accordingly, the 2 seaward species had slender and deeper crowns, and the 2 rhizophoraceous species had wider and flatter crowns, while $X$. granatum exhibited smaller crowns. For most of the species, shade saplings had a shallower crown, a larger crown area, or both, than sun saplings, although shade saplings of $X$. granatum had a deeper crown than sun saplings.

Fig. 4 shows the relationships between sapling height and total branch length, total leaf area, leafiness and tree LAI. Total branch length was greatest in
Sonneratia alba, intermediate in Avicennia alba and the 2 rhizophoraceous species, and lowest in Xylocarpus granatum (Fig. 4a). In gaps, total leaf area showed a similar pattern to total branch length. However, in closed canopies, total leaf area was greatest in the 2 rhizophoraceous species (Fig. 4b). As a result, leafiness (total leaf area per unit shoot length) in shade saplings was lowest in the 2 seaward species, intermediate in the 2 rhizophoraceous species, and greatest in $X$. granatum (Fig. 4c). Tree LAI in gaps was greater in the 2 seaward species and $X$. granatum than in the 2 rhizophoraceous species (Fig. 4d). For most of the species, total branch length and leaf area were greater in sun saplings than in shade saplings, while the opposite pattern was true for $X$. granatum.

\section{Leaf morphology and dynamics}

Leaf area was smaller in the 2 seaward species, intermediate in the 2 rhizophoraceous species and larger in Xylocarpus granatum (Table 3). The large leaf area of $X$. granatum was due to its even-pinnately compound leaf (Tomlinson 1986). Sonneratia alba exhibited the highest SLA among the 5 species, due to well-developed mesophyll and hypodermal mucous cells, which have a smaller specific weight per volume when dried (Tomlinson 1986). SLA was lower in sun saplings than in shade saplings for all species except Rhizophora apiculata.

Standing leaf number differed in the order Sonneratia alba $=$ Rhizophora apiculata $\leq$ Avicennia alba $=$

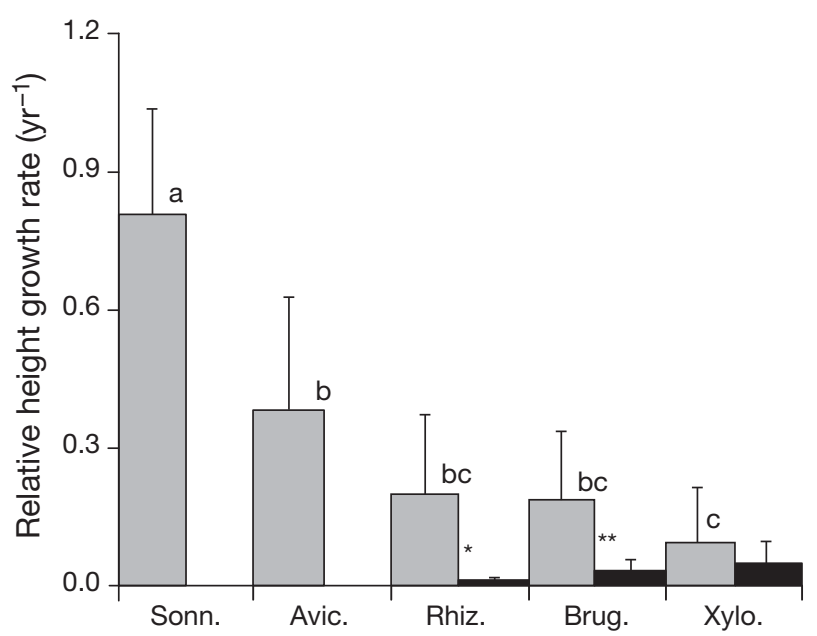

Fig. 1. Relative height growth rate of saplings of 5 mangrove species in gaps (grey bars) and closed canopies (black bars). Error bars indicate SD. Species sharing the same letters did not differ significantly at $\mathrm{p}<0.05$. Comparison of means between gaps and closed canopies: ${ }^{*} \mathrm{p}<0.05 ;{ }^{* *} \mathrm{p}<0.01$. Sonn.: Sonneratia alba; Avic.: Avicennia alba; Rhiz.: Rhizophora apiculata; Brug.: Bruguiera gymnorhiza; Xylo.: Xylocarpus granatum 
Table 2. Summary of SMATR results with sapling height $(\mathrm{H})$ as covariate. Species sharing the same letters did not differ significantly at $\mathrm{p}<0.05$. Comparison of means between gaps and closed canopies: ${ }^{*} \mathrm{p}<0.05 ;{ }^{* *} \mathrm{p}<0.01 ;{ }^{* * *} \mathrm{p}<0.001$. LAI: Leaf area index. The test for intercept is applicable only when the difference in slope is not significant. Full species names in Table 1

\begin{tabular}{|c|c|c|c|c|c|c|c|c|c|c|c|}
\hline \multirow[b]{2}{*}{ H-Stem mass } & \multirow[b]{2}{*}{$\begin{array}{l}\text { Gap } \\
\text { Closed }\end{array}$} & \multicolumn{2}{|c|}{$\begin{array}{c}\text { S. alba } \\
\text { Slope Intercept }\end{array}$} & \multicolumn{2}{|c|}{$\begin{array}{c}\text { A. alba } \\
\text { Slope Intercept }\end{array}$} & \multicolumn{2}{|c|}{$\begin{array}{c}R . \text { apiculata } \\
\text { Slope Intercept }\end{array}$} & \multicolumn{2}{|c|}{$\begin{array}{l}\text { B. gymnorhiza } \\
\text { Slope Intercept }\end{array}$} & \multicolumn{2}{|c|}{$\begin{array}{l}X . \text { granatum } \\
\text { Slope Intercept }\end{array}$} \\
\hline & & $\begin{array}{l}1.21 \\
1.06\end{array}$ & $\begin{array}{l}0.19^{\mathrm{a}} \\
0.27^{\mathrm{ab}}\end{array}$ & $\begin{array}{l}1.02 \\
1.10\end{array}$ & $\begin{array}{l}0.23^{\mathrm{a}} \\
0.08^{\mathrm{b}}\end{array}$ & $\begin{array}{l}0.61 \\
1.06\end{array}$ & $\begin{array}{c}0.89^{\mathrm{a}} \\
0.28^{\mathrm{ab}}\end{array}$ & $\begin{array}{l}0.85 \\
1.12\end{array}$ & $\begin{array}{l}0.65^{\mathrm{a}} \\
0.36^{\mathrm{a}}\end{array}$ & $\begin{array}{l}0.86 \\
1.16\end{array}$ & $\begin{array}{c}0.19^{\mathrm{b}} \\
-0.32^{\mathrm{c}}\end{array}$ \\
\hline H-Crown area & $\begin{array}{l}\text { Gap } \\
\text { Closed }\end{array}$ & $\begin{array}{c}0.48^{\mathrm{c}} \\
0.82^{\mathrm{b}} \\
{ }_{* * *}\end{array}$ & $\begin{array}{l}-0.27 \\
-0.66\end{array}$ & $\begin{array}{l}0.52^{\mathrm{bc}} \\
0.76^{\mathrm{bc}}\end{array}$ & $\begin{array}{l}-0.38 \\
-0.61\end{array}$ & $\begin{array}{l}0.70^{\mathrm{b}} \\
0.76^{\mathrm{b}}\end{array}$ & $\begin{array}{c}-0.04 \\
-0.24 \\
* *\end{array}$ & $\begin{array}{l}1.04^{\mathrm{a}} \\
1.31^{\mathrm{a}}\end{array}$ & $\begin{array}{l}-0.67 \\
-0.98\end{array}$ & $\begin{array}{c}0.08^{\mathrm{d}} \\
0.29^{\mathrm{c}} \\
* * *\end{array}$ & $\begin{array}{l}-0.02 \\
-0.26\end{array}$ \\
\hline $\begin{array}{l}\text { H-Crown } \\
\text { depth }\end{array}$ & $\begin{array}{l}\text { Gap } \\
\text { Closed }\end{array}$ & $\begin{array}{l}0.99^{\mathrm{a}} \\
0.98^{\mathrm{a}}\end{array}$ & $\begin{array}{l}0.002 \\
-0.22\end{array}$ & $\begin{array}{c}0.91^{\mathrm{a}} \\
0.62^{\mathrm{b}} \\
{ }^{* *}\end{array}$ & $\begin{array}{l}-0.11 \\
-0.10\end{array}$ & $\begin{array}{l}0.86^{\mathrm{a}} \\
0.51^{\mathrm{b}}\end{array}$ & $\begin{array}{c}-0.54 \\
-0.29 \\
* * *\end{array}$ & $\begin{array}{l}0.96^{\mathrm{a}} \\
0.74^{\mathrm{b}} \\
{ }_{* *}\end{array}$ & $\begin{array}{l}-0.69 \\
-0.55\end{array}$ & $\begin{array}{c}0.34^{\mathrm{b}} \\
0.56^{\mathrm{ab}} \\
{ }^{*}\end{array}$ & $\begin{array}{l}-0.22 \\
-0.45\end{array}$ \\
\hline $\begin{array}{l}\text { H-Total } \\
\text { branch length }\end{array}$ & $\begin{array}{l}\text { Gap } \\
\text { Closed }\end{array}$ & $\begin{array}{c}20.5^{\mathrm{a}} \\
9.5^{\mathrm{a}} \\
*^{* *}\end{array}$ & $\begin{array}{l}-14.8 \\
-7.1\end{array}$ & $\begin{array}{c}7.0^{\mathrm{b}} \\
4.6^{\mathrm{b}} \\
*\end{array}$ & $\begin{array}{l}-5.1 \\
-3.5\end{array}$ & $\begin{array}{c}7.1^{\mathrm{b}} \\
4.0^{\mathrm{b}} \\
* *\end{array}$ & $\begin{array}{l}-4.9 \\
-3.0\end{array}$ & $\begin{array}{l}5.5^{\mathrm{b}} \\
4.4^{\mathrm{b}} \\
* *\end{array}$ & $\begin{array}{l}-4.3 \\
-3.8\end{array}$ & $\begin{array}{l}0.1^{\mathrm{c}} \\
1.0^{\mathrm{c}} \\
* * *\end{array}$ & $\begin{array}{l}-0.1 \\
-1.2\end{array}$ \\
\hline $\begin{array}{l}\text { H-Total } \\
\text { leaf area }\end{array}$ & $\begin{array}{l}\text { Gap } \\
\text { Closed }\end{array}$ & $\begin{array}{c}2.15^{\mathrm{a}} \\
0.48^{\mathrm{bc}} \\
{ }^{* * *}\end{array}$ & $\begin{array}{l}-1.51 \\
-0.35\end{array}$ & $\begin{array}{l}0.41^{\mathrm{c}} \\
0.30^{\mathrm{d}}\end{array}$ & $\begin{array}{l}-0.25 \\
-0.20\end{array}$ & $\begin{array}{l}1.30^{\mathrm{b}} \\
0.74^{\mathrm{ab}}\end{array}$ & $\begin{array}{l}-0.86 \\
-0.61\end{array}$ & $\begin{array}{c}1.31^{\mathrm{b}} \\
0.94^{\mathrm{a}} \\
{ }^{*}\end{array}$ & $\begin{array}{l}-1.06 \\
-0.71\end{array}$ & $\begin{array}{l}0.17^{\mathrm{d}} \\
0.45^{\mathrm{c}} \\
{ }^{* *}\end{array}$ & $\begin{array}{l}-0.08 \\
-0.38\end{array}$ \\
\hline H-Leafiness & $\begin{array}{l}\text { Gap } \\
\text { Closed }\end{array}$ & $\begin{array}{c}0.02^{\text {bd }} \\
0.01^{\mathrm{c}}\end{array}$ & $\begin{array}{l}0.07 \\
0.02\end{array}$ & $\begin{array}{c}-0.01^{\mathrm{d}} \\
0.01^{\mathrm{c}}\end{array}$ & $\begin{array}{c}0.07 \\
0.03 \\
*\end{array}$ & $\begin{array}{l}0.04^{\mathrm{ab}} \\
0.05^{\mathrm{b}}\end{array}$ & $\begin{array}{l}0.08 \\
0.03 \\
* * *\end{array}$ & $\begin{array}{l}0.07^{\mathrm{ac}} \\
0.06^{\mathrm{ab}}\end{array}$ & $\begin{array}{l}0.04 \\
0.05\end{array}$ & $\begin{array}{l}0.03^{\mathrm{c}} \\
0.10^{\mathrm{a}}\end{array}$ & $\begin{array}{c}0.07 \\
-0.002\end{array}$ \\
\hline H-Tree LAI & $\begin{array}{l}\text { Gap } \\
\text { Closed }\end{array}$ & $\begin{array}{c}0.87^{\mathrm{a}} \\
-0.23^{\mathrm{ac}} \\
* *\end{array}$ & $\begin{array}{l}2.21 \\
1.11\end{array}$ & $\begin{array}{l}-0.94^{\mathrm{a}} \\
-0.21^{\mathrm{c}}\end{array}$ & $\begin{array}{l}2.86 \\
1.06 \\
* * *\end{array}$ & $\begin{array}{c}0.39^{\mathrm{b}} \\
0.15^{\mathrm{a}} \\
{ }_{* *}\end{array}$ & $\begin{array}{c}0.04 \\
0.006\end{array}$ & $\begin{array}{l}0.23^{\mathrm{b}} \\
0.10^{\mathrm{a}}\end{array}$ & $\begin{array}{c}0.59 \\
0.50 \\
*\end{array}$ & $\begin{array}{l}0.16^{\mathrm{a}} \\
0.16^{\mathrm{b}}\end{array}$ & $\begin{array}{l}1.57 \\
1.59\end{array}$ \\
\hline
\end{tabular}

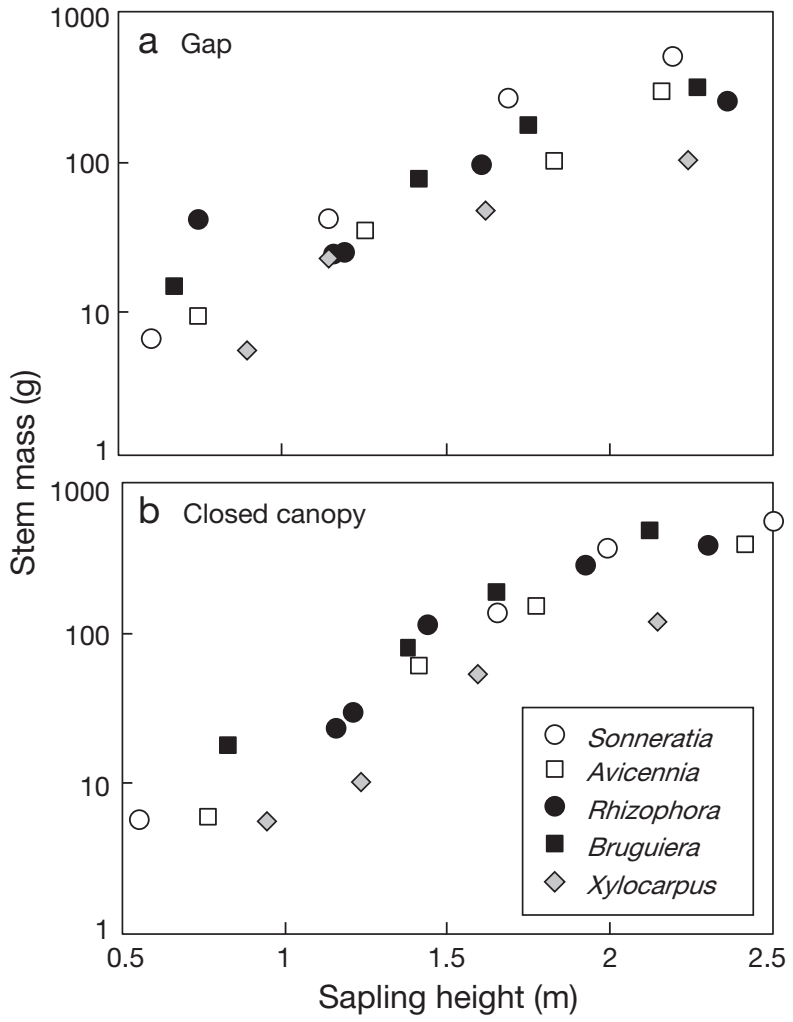

Fig. 2. Relationship between sapling height and stem mass (log-transformed) of saplings of 5 mangrove species in (a) gaps and (b) closed canopies. Inter- and intraspecific differences were tested by SMATR; results are shown in Table 2
Xylocarpus granatum $\leq$ Bruguiera gymnorhiza. Leaf longevity in gaps was the shortest in $S$. alba (0.36 yr), and increased from seaward to inland species $(0.65$, $1.05,1.53$, and 2.66 yr in A. alba, R. apiculata, B. gymnorhiza and $X$. granatum, respectively) due to a decrease in both loss and production rate of leaves from seaward to inland species. Leaf longevity in closed canopies was shortest in $R$. apiculata (1.19 yr), intermediate in B. gymnorhiza (1.41 yr) and longest in $X$. granatum (2.44 yr), but the difference between $B$. gymnorhiza and $X$. granatum was not significant. Leaf longevity of the 3 inland species did not differ significantly between gaps and closed canopies. Among the 5 species, leaf longevity in gaps was negatively correlated with RHGR (both log-log transformed; $\mathrm{r}^{2}=0.975$, $\mathrm{p}<0.01, \mathrm{n}=5$ ).

\section{DISCUSSION}

Growth response to gaps and closed canopies differed significantly among the 5 canopy-dominant species in tropical mangrove forests in Ranong, Thailand. The 2 seaward species, Sonneratia alba and Avicennia alba, grew rapidly in gaps while showing high mortality under closed canopies. Thus, the density of saplings ( 0.5 to $2 \mathrm{~m}$ tall) and young trees $(>2 \mathrm{~m}$ tall, $<5 \mathrm{~cm}$ diameter) of these seaward species were higher in gaps than under closed canopies. These species may thus 

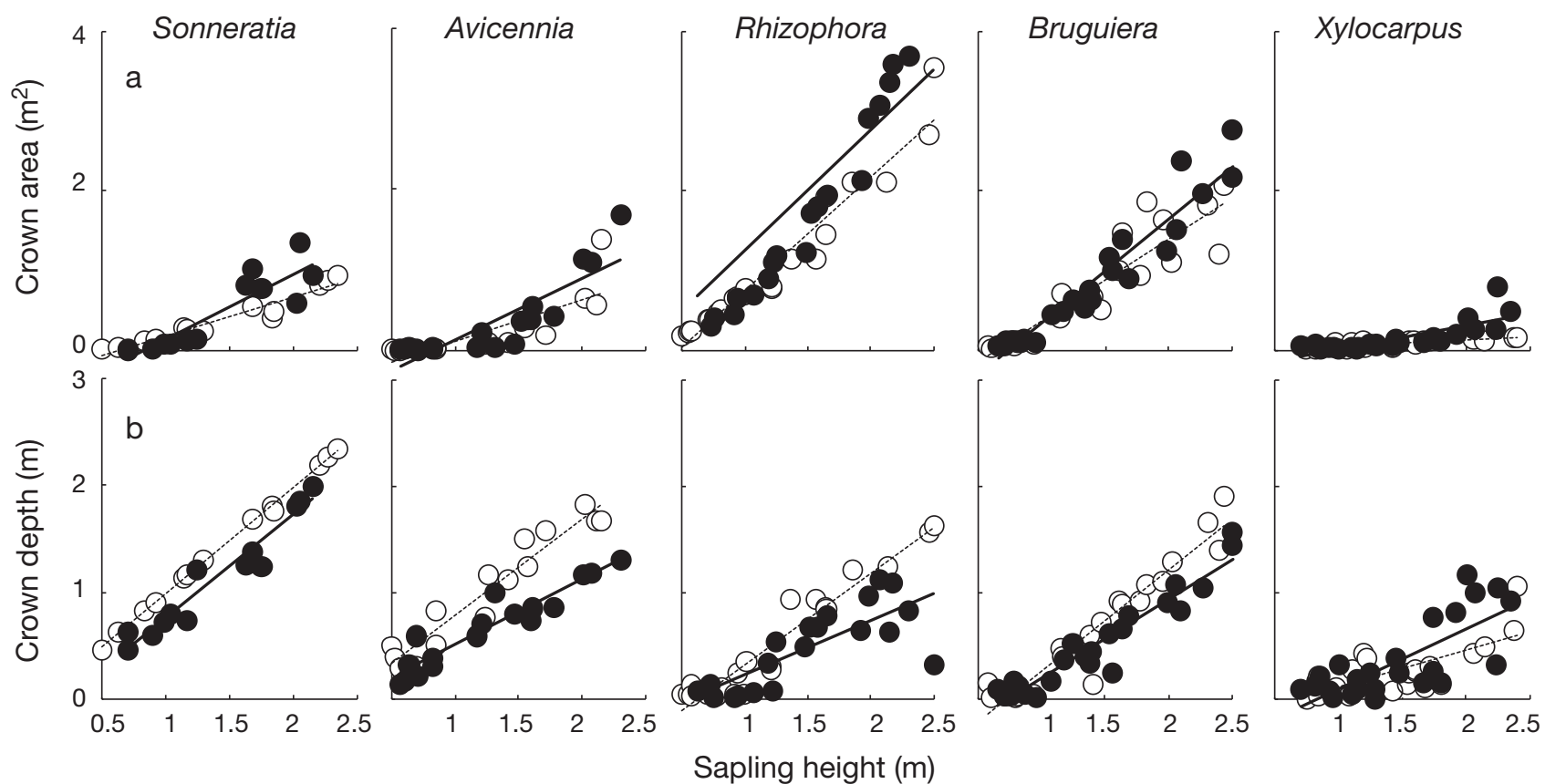

Fig. 3. Relationships between tree height and (a) crown area and (b) crown depth of saplings of 5 mangrove species in gaps (O) and closed canopies (๑). Regressions are shown for gaps (broken lines) and closed canopies (solid lines); all were correlated significantly at $\mathrm{p}<0.001$. Inter- and intraspecific differences were tested by SMATR; results are shown in Table 2

depend on gap formation for successful establishment and growth. In contrast, the 3 inland species, Rhizophora apiculata, Bruguiera gymnorhiza and Xylocarpus granatum, showed slower RHGR than those of the 2 seaward species in gaps, but they could survive and grow under closed canopies. The establishment of a sapling bank in these species under closed canopies in spite of dark conditions (Imai et al. 2006) is probably related to their shade tolerance. Previous studies have described a similar growth response of these species (Tamai \& Iampa 1988, Duarte et al. 1999, Pinzón et al. 2003).

The difference in growth strategy (potential growth rate and shade tolerance) among the 5 species reflected the difference in leaf phenological traits and crown architecture. The 2 seaward species had shorter leaf

Table 3. Leaf morphology and dynamics of saplings of 5 mangrove species in gaps and closed canopies. Species sharing the same letters did not differ significantly at $\mathrm{p}<0.05$. Asterisks show the probability of significance in comparison of means between gaps and closed canopies: ${ }^{*} \mathrm{p}<0.05 ;{ }^{* *} \mathrm{p}<0.01 ;{ }^{* * *} \mathrm{p}<0.001$. Sonneratia alba; Avicennia alba; Rhizophora apiculata; Bruguiera gymnorhiza; Xylocarpus granatum

\begin{tabular}{|c|c|c|c|c|c|c|c|c|c|c|c|}
\hline \multirow{2}{*}{ Leaf morphology } & & \multicolumn{2}{|c|}{ Sonneratia } & \multicolumn{2}{|c|}{ Avicennia } & \multicolumn{2}{|c|}{ Rhizophora } & \multicolumn{2}{|c|}{ Bruguiera } & \multicolumn{2}{|c|}{ Xylocarpus } \\
\hline & & Mean & $\mathrm{SD}$ & Mean & $\mathrm{SD}$ & Mean & $\mathrm{SD}$ & Mean & $\mathrm{SD}$ & Mean & $\mathrm{SD}$ \\
\hline $\begin{array}{l}\text { Leaf morphology } \\
\text { Leaf area }\left(\mathrm{cm}^{2}\right)\end{array}$ & $\begin{array}{l}\text { Gap } \\
\text { Closed }\end{array}$ & $\begin{array}{l}23.0^{\mathrm{b}} \\
20.5^{\mathrm{d}}\end{array}$ & $\begin{array}{l}7.4 \\
9.4\end{array}$ & $\begin{array}{l}22.5^{\mathrm{b}} \\
27.4^{\mathrm{c}}\end{array}$ & $\begin{array}{l}5.2 \\
6.4\end{array}$ & $\begin{array}{l}67.0^{\mathrm{a}} \\
66.0^{\mathrm{b}}\end{array}$ & $\begin{array}{l}13.0 \\
17.2\end{array}$ & $\begin{array}{l}71.0^{\mathrm{a}} \\
82.6^{\mathrm{ab}}\end{array}$ & $\begin{array}{l}12.0 \\
18.4\end{array}$ & $\begin{array}{l}83.4^{\mathrm{a}} \\
100.5^{\mathrm{a}}\end{array}$ & $\begin{array}{l}29.9 \\
33.1\end{array}$ \\
\hline SLA $\left(\mathrm{cm}^{2} \mathrm{~g}^{-1}\right)$ & $\begin{array}{l}\text { Gap } \\
\text { Closed }\end{array}$ & $\begin{array}{c}140.5^{\mathrm{a}} \\
166.9^{\mathrm{a}} \\
{ }^{*}\end{array}$ & $\begin{array}{l}28.8 \\
29.9\end{array}$ & $\begin{array}{l}65.2^{\mathrm{b}} \\
95.9^{\mathrm{b}} \\
* * * *\end{array}$ & $\begin{array}{c}7.7 \\
12.2\end{array}$ & $\begin{array}{l}70.5^{\mathrm{b}} \\
76.4^{\mathrm{c}}\end{array}$ & $\begin{array}{l}7.2 \\
8.7\end{array}$ & $\begin{array}{l}63.9^{\mathrm{b}} \\
77.6^{\mathrm{c}} \\
* * *\end{array}$ & $\begin{array}{l}10.3 \\
7.4\end{array}$ & $\begin{array}{c}78.2^{\mathrm{b}} \\
101.4^{\mathrm{b}} \\
* * *\end{array}$ & $\begin{array}{l}13.2 \\
11.6\end{array}$ \\
\hline $\begin{array}{l}\text { Leaf dynamics } \\
\text { Standing leaf } \\
\text { number (no. shoot }{ }^{-1} \text { ) }\end{array}$ & $\begin{array}{l}\text { Gap } \\
\text { Closed }\end{array}$ & $\begin{array}{c}8.4^{\mathrm{b}} \\
-\end{array}$ & 0.7 & $\begin{array}{c}10.9^{\mathrm{ab}} \\
-\end{array}$ & 2.4 & $\begin{array}{c}8.3^{\mathrm{b}} \\
8.8\end{array}$ & $\begin{array}{l}1.3 \\
1.6\end{array}$ & $\begin{array}{l}12.6^{\mathrm{a}} \\
12.0\end{array}$ & $\begin{array}{l}2.2 \\
1.8\end{array}$ & $\begin{array}{c}10.2^{\mathrm{ab}} \\
9.9\end{array}$ & $\begin{array}{l}4.2 \\
8.9\end{array}$ \\
\hline $\begin{array}{l}\text { Leaf loss rate } \\
\left(\text { no. } \mathrm{yr}^{-1} \text { shoot }^{-1}\right)\end{array}$ & $\begin{array}{l}\text { Gap } \\
\text { Closed }\end{array}$ & $\begin{array}{c}24.9^{\mathrm{a}} \\
-\end{array}$ & 3.6 & $\begin{array}{c}18.6^{\mathrm{b}} \\
-\end{array}$ & 3.6 & $\begin{array}{l}7.8^{\mathrm{c}} \\
7.7^{\mathrm{a}}\end{array}$ & $\begin{array}{l}1.2 \\
1.7\end{array}$ & $\begin{array}{l}7.4^{\mathrm{c}} \\
8.7^{\mathrm{a}} \\
*\end{array}$ & $\begin{array}{l}1.0 \\
1.4\end{array}$ & $\begin{array}{l}4.4^{\mathrm{c}} \\
4.4^{\mathrm{b}}\end{array}$ & $\begin{array}{l}2.1 \\
3.3\end{array}$ \\
\hline $\begin{array}{l}\text { Leaf production rate } \\
\left(\text { no. } \mathrm{yr}^{-1} \text { shoot }^{-1}\right)\end{array}$ & $\begin{array}{l}\text { Gap } \\
\text { Closed }\end{array}$ & $\begin{array}{c}23.5^{\mathrm{a}} \\
-\end{array}$ & 3.8 & $\begin{array}{c}17.3^{\mathrm{b}} \\
-\end{array}$ & 4.3 & $\begin{array}{l}8.1^{\mathrm{cd}} \\
7.2^{\mathrm{a}} \\
*\end{array}$ & $\begin{array}{l}0.8 \\
0.8\end{array}$ & $\begin{array}{l}9.5^{\mathrm{c}} \\
8.7^{\mathrm{a}}\end{array}$ & $\begin{array}{l}1.4 \\
1.2\end{array}$ & $\begin{array}{l}3.6^{\mathrm{d}} \\
3.9^{\mathrm{b}}\end{array}$ & $\begin{array}{l}2.7 \\
2.9\end{array}$ \\
\hline Leaf longevity (yr) & $\begin{array}{l}\text { Gap } \\
\text { Closed }\end{array}$ & $\begin{array}{c}0.36^{\mathrm{a}} \\
-\end{array}$ & 0.03 & $\begin{array}{c}0.65^{\mathrm{ab}} \\
-\end{array}$ & 0.15 & $\begin{array}{l}1.05^{\mathrm{bc}} \\
1.19^{\mathrm{a}}\end{array}$ & $\begin{array}{l}0.18 \\
0.12\end{array}$ & $\begin{array}{l}1.53^{\mathrm{c}} \\
1.41^{\mathrm{b}}\end{array}$ & $\begin{array}{l}0.33 \\
0.28\end{array}$ & $\begin{array}{l}2.66^{\mathrm{d}} \\
2.44^{\mathrm{b}}\end{array}$ & $\begin{array}{c}0.9 \\
0.93\end{array}$ \\
\hline
\end{tabular}




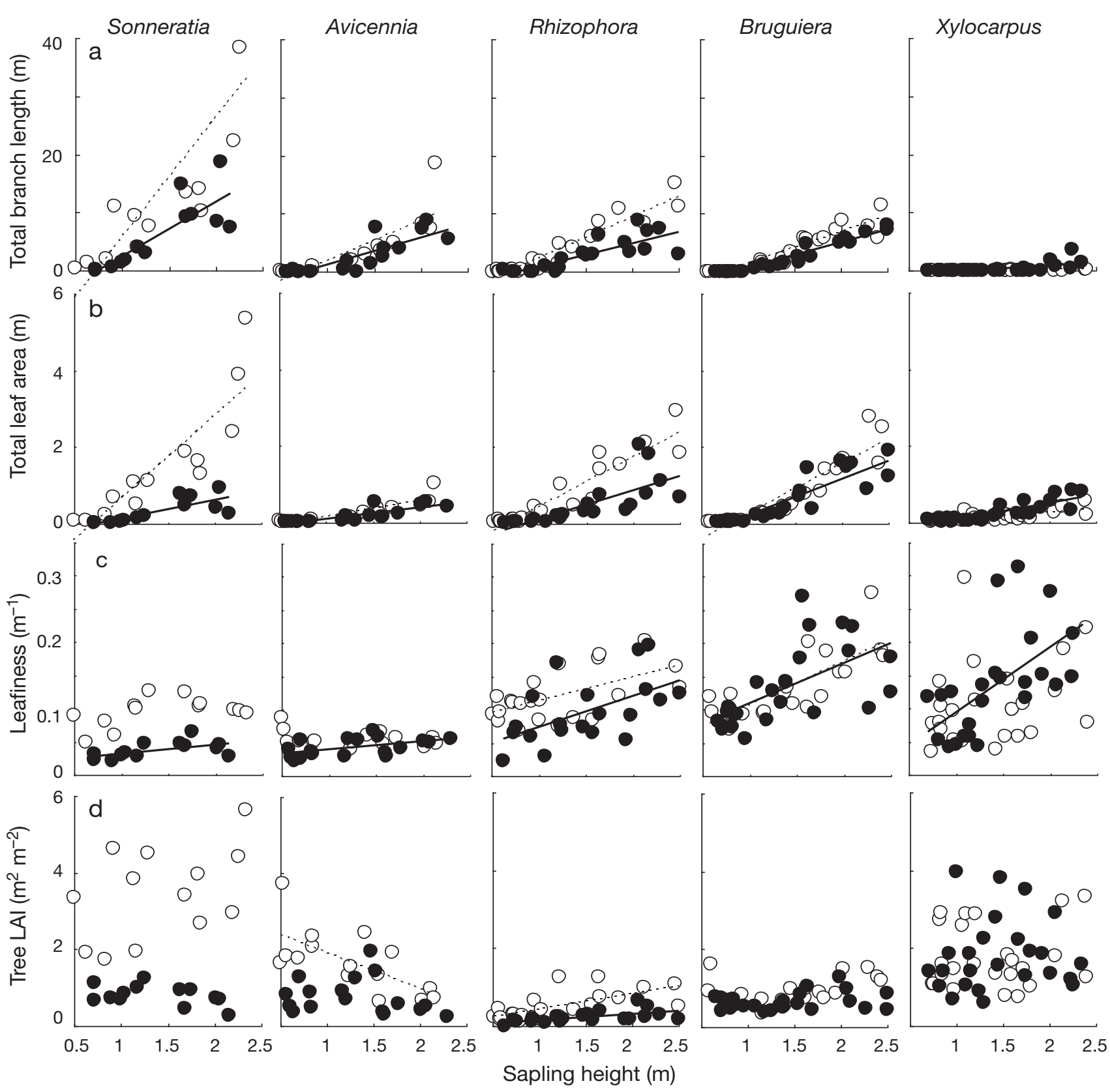

Fig. 4. Relationships between sapling height and (a) total branch length, (b) total leaf area, (c) leafiness and (d) tree leaf area index (LAI) of saplings of 5 mangrove species in gaps (O) and closed canopies ( ) Regressions are shown for gaps (broken lines) and closed canopies (solid lines). Only relationships significant at $\mathrm{p}<0.05$ are shown. Inter- and intraspecific differences were tested by SMATR; results are shown in Table 2

longevity than the 3 inland species. Short leaf longevity (i.e. a high turnover rate of leaves) is often associated with a higher relative growth rate and a higher photosynthetic assimilation rate (Reich et al. 1991). Kitao et al. (2003) reported that the light-saturated electron transport rate, which can be correlated with the photosynthetic rate, was highest in Sonneratia alba, followed by Rhizophora apiculata and Bruguiera gymnorhiza, and was lowest in Xylocarpus granatum (Avicennia alba was not measured). The result from the present study that leaf longevity is negatively correlated with RHGR in gaps implies that leaf-level traits (leaf turnover and photosynthesis) correspond directly to the individual-level growth rate in mangrove saplings.

Light-demanding species generally have a slender crown that may consist of a dense display of leaves. A slender crown has been interpreted as requiring less support tissue and an increased tree LAI, thus allowing 
for more rapid height growth (Canham 1988). The slender, deeper crown and greater tree LAI of Sonneratia alba and Avicennia alba agree with this interpretation (Fig. 4d). On the other hand, these species showed high mortality under closed canopies because their leaf display pattern induces self-shading and high-cost crown maintenance, which in turn threatens the survival of saplings.

Light-demanding species generally have lessbranched, slender crowns, and often exhibit larger leaves. However, Sonneratia alba and Avicennia alba had well-branched (but slender) crowns and small leaves. Thus, these 2 seaward species showed a greater leafiness value than the 2 rhizophoraceous species (Fig. 4c) and a stem mass per unit height similar to the 2 rhizophoraceous species (Fig. 2). These results indicate that $S$. alba and $A$. alba, in spite of being light-demanding species, have to pay a relatively high cost for leaf support and resultant extension growth. Turner et al. (1995) also reported a similarity of biomass allocation among mangrove tree species including S. alba, A. alba and Rhizophora apiculata in the Malaysian Peninsula. Although structural traits (leaf size and crown architecture) and the inherent growth rate are considered to be mutually related, $S$. alba and $A$. alba do not demonstrate such a relationship. S. alba and A. alba are specialists at colonizing newly deposited, saline, anaerobic and littoral substrates with frequent tidal inundation (Lee et al. 1996, Panapitukkul et al. 1998, Thampanya et al. 2002). These 2 seaward species have a robust stem (larger stem mass per unit height), which results in improved resistance to physical damage by tides. A wellbranched crown and enhanced sprouting ability of these species (Tsuda \& Ajima 1999, N. Imai pers. obs.) may contribute to their resilience by allowing sprouting and branching when physical damage occurs. Additionally, the small leaves of these species may be less affected by tidal inundation. Species with smaller leaves are superior in maintaining and expanding an assimilation system at any given height over a long time (Kohyama 1987), although they have higher costs for supporting a greater number of leaves by allocating photosynthate to lateral branches than larger-leaved species. All these characteristics are advantageous for sapling establishment and growth under severe intertidal conditions. In contrast, structural traits of lightdemanding species (e.g. smaller leaves, thinner stems and a less-branched, smaller crown) may be disadvantageous for mechanical damage. Therefore, evolutionary pressures of the structural trade-off may not have operated on the 2 seaward species. Similar morphological features can be seen in some fast-growing tree species (e.g. Populus spp. and Salix spp.) in terrestrial forests experiencing large or frequent disturbances.
In contrast to the seaward species, the 2 rhizophoraceous species, Rhizophora apiculata and Bruguiera gymnorhiza, had longer leaf longevity and a wider, flatter crown. Longer leaf longevity (with a concomitant lower photosynthetic rate) has been thought to contribute to shade tolerance because extended leaf longevity compensates for low productivity in shade (Chabot \& Hicks 1982). The wide and relatively wellbranched crown of the 2 rhizophoraceous species also may contribute to effective light capture without selfshading under a closed canopy (Horn 1971).

Although these rhizophoraceous species had greater adaptations to shady conditions than the 2 seaward light-demanding species, Rhizophora apiculata and Bruguiera gymnorhiza cannot simply be considered as shade-tolerant species. Classification of mangrove species as shade-tolerant or -intolerant has been previously discussed (Macnae 1968, Putz \& Chan 1986, Sukardjo 1987, Pinzón et al. 2003). Rhizophora has been considered a shade-tolerant genus (Ball 1980) on the basis that its seedlings are frequently observed under a range of canopy conditions; however, some studies report the gap-dependency of Rhizophora based on its greater seedling density and growth in gaps (Smith 1992, Smith et al. 1994, Sousa et al. 2003). Recent individual-based model simulations of an $R$. mangle population in the neotropics have supported this species being dependent on light-gap disturbances for regeneration (Chen \& Twilley 1998, Berger \& Hildenbrandt 2000, Berger et al. 2008, López-Hoffman et al. 2007). López-Hoffman et al. (2007) suggested that the strategy of $R$. mangle is to constantly produce a large number of seedlings and to establish a seedling bank so that at least some are likely to directly colonize a canopy gap. This interpretation may be applied to $R$. apiculata, which can survive in shade and grow rapidly in gaps (Tamai \& Iampa 1988, Pinzón et al. 2003, present study).

Xylocarpus granatum showed a contrasting crown architecture to that of the 2 rhizophoraceous species, although the 3 species showed a similar growth response. $X$. granatum had exceptionally low biomass per unit sapling height compared with the other species due to effective leaf display with little or no investment per branch (Fig. 4a). This species has large compound leaves that may function as expendable branches, with a lower construction cost than that of genuine branches (Givnish 1978). Thus, X. granatum saplings could have a small crown with a low extension cost, contributing to growth under a closed canopy. In addition, shade saplings of $X$. granatum surprisingly increased total leaf area to the same extent that sun saplings did (Fig. 4b), probably because of a negative influence of high light on sun leaves due to less effective protective mechanisms against photoinhibition (Kitao et al. 2003). 
The growth strategy of each of the canopy-dominant species matched the disturbance regime in the zone in which they dominate. Imai et al. (2006) showed that mean canopy gap size was substantially larger in the SA zone (144 to $165 \mathrm{~m}^{2}$ ) than in the other zones (30 to $67 \mathrm{~m}^{2}$ ), and percent gap area was also greater in the SA zone (23 to $29 \%$ ) than in the other zones (5 to $8 \%$ ). The densities of Sonneratia alba and Avicennia alba saplings and young trees were greater in gaps than in closed canopies due to their characteristics as lightdemanding species. Consequently, formation of many large gaps may facilitate the establishment and growth of $S$. alba and A. alba in the SA zone. As noted above, the robust structure of the 2 seaward species also contributed to their ability to colonize their habitat of newly deposited substrates. On the other hand, the 3 inland zones ( $\mathrm{Ra}, \mathrm{RB}$ and $\mathrm{CX}$ zones) had small canopy gaps. Because the 3 inland species can tolerate darker conditions than $S$. alba and A. alba, they showed greater densities of saplings and young trees in closed canopies than in gaps in the zones in which they are dominant. These species may not need large gaps for their establishment and growth. A low number of large gaps may prevent the light-demanding species from establishing and growing in inland zones. Accordingly, the correspondence of disturbance regime and growth strategies of canopy-dominant species provides an advantage for successful regeneration, and may contribute to the maintenance of the present species composition in each vegetation zone. Species composition in mangrove forests is primarily regulated by soil conditions (e.g. salinity, fertility, sulfide concentrations and redox potential) and flooding patterns related to regional geomorphology (Thom 1967, Thom et al. 1975, Wolanski et al. 1992, Woodroffe 1992). Seed dispersal ability (Clarke et al. 2001), differential consumption of propagules (Smith 1987, Smith et al. 1989) and interspecific competition (Ball 1980) are also proposed as critical factors for the regeneration process, which eventually affects the distribution and abundance of mangrove tree species. Although such factors primarily determine the species composition of a mangrove forest, in short-term forest dynamics without a large geomorphological change, species composition may change little in each forest zone due to the growth strategies of dominant species and the disturbance regime in each zone.

Acknowledgements. We thank T. Nakamura, S. Aksornkoae, S. Havanon and W. Meepol for their valuable advice and helpful discussions. K. Kitayama and an anonymous reviewer provided helpful comments on an earlier version of this manuscript. We acknowledge the staff of Ranong Mangrove Forest Research Centre and the members of the Laboratory of Forest Ecology, Department of Forest Science, Tokyo Univer- sity of Agriculture for their support in the field research. Permission to work in the mangrove forests of Thailand was granted by the National Research Council of Thailand. This work was supported by the Global Environment Research Fund (F-071) of the Ministry of the Environment, Japan.

\section{LITERATURE CITED}

Allen JA, Ewel KC, Jack J (2001) Patterns of natural and anthropogenic disturbance of the mangroves on the Pacific Island of Kosrae. Wetlands Ecol Manage 9:291-301

Ball MC (1980) Patterns of secondary succession in a mangrove forest of southern Florida. Oecologia 44:226-235

> Berger U, Hildenbrandt H (2000) A new approach to spatially explicit modeling of forest dynamics: spacing, ageing and neighborhood competition of mangrove trees. Ecol Model 132:287-302

Berger U, Rivera-Monroy VH, Doyle TW, Dahdouh-Guebas F and others (2008) Advances and limitations of individualbased models to analyze and predict dynamics of mangrove forests: a review. Aquat Bot 89:260-274

Canham CD (1988) Growth and canopy architecture of shade-tolerant trees: response to canopy gaps. Ecology 69:786-795

Chabot BF, Hicks DJ (1982) The ecology of leaf life spans. Annu Rev Ecol Syst 13:229-259

Chen R, Twilley RR (1998) A gap dynamic model of mangrove forest development along gradients of soil salinity and nutrient resources. J Ecol 86:37-51

Clarke PJ (2004) Effects of experimental canopy gaps on mangrove recruitment: lack of habitat partitioning may explain stand dominance. J Ecol 92:203-213

Clarke PJ, Kerrigan RA, Westphal CJ (2001) Dispersal potential and early growth in 14 tropical mangroves: Do early life history traits correlate with patterns of adult distribution? J Ecol 89:648-659

Duarte CM, Thampanya U, Terrados J, Geertz-Hansen O, Fortes MD (1999) The determination of the age and growth of SE Asian mangrove seedlings from internodal counts. Mangroves Salt Marshes 3:251-257

Ellison AM, Farnsworth EJ (1993) Seedling survivorship, growth, and response to disturbance in Belizean mangal. Am J Bot 80:1137-1145

Falster DS, Warton DI, Wright IJ (2006) SMATR: standardised major axis tests and routines, version 2. Available at www.bio.mq.edu.au/ecology/SMATR/

> Farnsworth EJ, Ellison AM (1996) Sun-shade adaptability of the red mangrove, Rhizophora mangle (Rhizophoraceae): changes through ontogeny at several levels of biological organization. Am J Bot 83:1131-1143

- Feller IC, McKee KL (1999) Small gap creation in Belizean mangrove forests by a wood-boring insect. Biotropica 31: $607-617$

Givnish T (1978) On the adaptation significance of compound leaves: with particular reference to tropical rain trees. In: Tomlinson PB, Zimmermann MH (ed) Tropical trees as living systems. Cambridge University Press, Cambridge, p 351-380

> Gower ST, Reich PB, Son Y (1993) Canopy dynamics and aboveground production of 5 tree species with different leaf longevities. Tree Physiol 12:327-345

Horn HS (1971) The adaptive geometry of trees. Princeton University Press, Princeton, NJ

> Imai N, Takyu M, Nakamura Y, Nakamura T (2006) Gap formation and regeneration of tropical mangrove forests in Ranong, Thailand. Plant Ecol 186:37-46

Jiménez JA, Lugo AE, Cintrón G (1985) Tree mortality in 
mangrove forests. Biotropica 17:177-185

Kitao M, Utsugi H, Shigeo K, Tabuchi R, Fujimoto K, Lihpai S (2003) Light-dependent photosynthetic characteristics indicated by chlorophyll fluorescence in five mangrove species native to Pohnpei Island, Micronesia. Physiol Plant 117:376-382

Kohyama T (1987) Significance of architecture and allometry in saplings. Funct Ecol 1:399-404

Lee SK, Tan WK, Havanond S (1996) Regeneration and colonization of mangrove on clay-filled reclaimed land in Singapore. Hydrobiologia 319:23-35

López-Hoffman L, Ackerly DD, Anten NPR, DeNoyer JL, Martínez-Ramos M (2007) Gap-dependence in mangrove life-history strategies: a consideration of the entire life cycle and patch dynamics. J Ecol 95:1222-1233

Macintosh DJ, Aksornkoae S, Vannucci M, Field CD and others (1991) Integrated multidisciplinary survey and research programme of the Ranong mangrove ecosystem: final report. UNDP/UNESCO, National Mangrove Committee of the National Research Council of Thailand, Bangkok, RAS/86/120

> Macnae W (1968) A general account of the fauna and flora of mangrove swamps and forests in the Indo-West-Pacific region. Adv Mar Biol 6:73-270

McKee KL (1995) Seedling recruitment patterns in a Belizean mangrove forest: effects of establishment ability and physico-chemical factors. Oecologia 101:448-460

Miyawaki A, Okuda S, Suzuki K, Fujiwara K and others (1985) Phytosociological studies of mangrove vegetation in Thailand. In: Miyawaki A (ed) Ecological studies on the vegetation of mangrove forests in Thailand. Yokohama National University, Yokohama, p 1-100

Mochida Y, Fujimoto K, Miyagi T, Ishihara S, Murofushi T, Kikuchi T, Pramojanee P (1999) A phytosociological study of the mangrove vegetation in the Malay Peninsula. Tropics 8:207-220

> Navas ML, Ducout B, Roumet C, Richarte J, Garnier J, Garnier E (2003) Leaf life span, dynamics and construction cost of species from Mediterranean old-fields differing in successional status. New Phytol 159:213-228

Ochieng CA, Erftemeijer PL (2002) Phenology, litterfall and nutrient resorption in Avicennia marina (Forssk.) Vierh in Gazi Bay, Kenya. Trees 16:167-171

Panapitukkul N, Duarte CM, Thampanya U, Kheowvongsri P and others (1998) Mangrove colonization: mangrove progression over the growing Pak Phanang (SE Thailand) mud flat. Estuar Coast Shelf Sci 47:51-61

Pinzón ZS, Ewel KC, Putz FE (2003) Gap formation and forest regeneration in a Micronesian mangrove forest. J Trop Ecol 19:143-153

Poorter L, Bongers F (2006) Leaf traits are good predictors of plant performance across 53 rain forest species. Ecology 87:1733-1743

Putz FE, Chan HT (1986) Tree growth, dynamics, and productivity in a mature mangrove forest in Malaysia. For Ecol Manage 17:211-230

Rabinowitz D (1978) Mortality and initial propagule size in mangrove seedlings in Panama. J Ecol 66:45-51

Reich PB, Uhl C, Walters MB, Ellsworth DS (1991) Leaf lifespan as a determinant of leaf structure and function among 23 amazonian tree species. Oecologia 86:16-24

Reich PB, Walters MB, Ellsworth DS (1992) Leaf life-span in relation to leaf, plant, and stand characteristics among diverse ecosystems. Ecol Monogr 62:365-392

Sherman RE, Fahey TJ, Battles JJ (2000) Small-scale disturbance and regeneration dynamics in a neotropical man- grove forest. J Ecol 88:165-178

Sherman RE, Fahey TJ, Martinez P (2001) Hurricane impacts on a mangrove forest in the Dominican Republic: damage patterns and early recovery. Biotropica 33: 393-408

Shukla RP, Ramakrishanan PS (1984) Leaf dynamics of tropical trees related to successional status. New Phytol 97: 697-706

$>$ Smith TJ III (1987) Seed predation in relation to tree dominance and distribution in mangrove forests. Ecology 68: $266-273$

Smith TJ III (1992) Forest structure. In: Robertson AI, Alongi DM (eds) Tropical mangrove ecosystems. American Geophysical Union, Washington, DC, p 101-136

Smith TJ III, Chan HT, McIvor CC, Robblee MB (1989) Comparisons of seed predation in tropical tidal forests from three continents. Ecology 70:146-151

Smith TJ III, Robblee MB, Wanless HR, Doyle TW (1994) Mangroves, hurricanes, and lightning strikes. BioScience 44:256-262

> Sousa WP, Quek SP, Mitchell BJ (2003) Regeneration of Rhizophora mangle in a Caribbean mangrove forest: interacting effects of canopy disturbance and a stem-boring beetle. Oecologia 137:436-445

> Sukardjo S (1987) Natural regeneration status of commercial mangrove species (Rhizophora apiculata and Bruguiera gymnorrhiza) in the mangrove forest of Tanjung Bungin, Banyuasin District, South Sumatra. For Ecol Manage 20: 233-252

Takahashi K, Rustandi A (2006) Responses of crown development to canopy openings by saplings of eight tropical submontane forest tree species in Indonesia: a comparison with cool-temperate trees. Ann Bot 97:559-569

Takahashi K, Seino T, Kohyama T (2001) Responses to canopy openings in architectural development of saplings in eight deciduous broad-leaved tree species. Can J For Res 31: 1336-1347

Tamai S, Iampa P (1988) Establishment and growth of mangrove seedlings in mangrove forests of southern Thailand. Ecol Res 3:227-238

Thampanya U, Vermaat JE, Duarte CM (2002) Colonization success of common Thai mangrove species as a function of shelter from water movement. Mar Ecol Prog Ser 237: $111-120$

Thom BG (1967) Mangrove ecology and deltaic geomorphology: Tabasco, Mexico. J Ecol 55:301-343

Thom BG, Wright LD, Coleman JM (1975) Mangrove ecology and deltaic-estuarine geomorphology: Cambridge GulfOrd River, Western. Aust J Ecol 63:203-232

Tomlinson PB (1986) The botany of mangroves. Cambridge University Press, Cambridge

Tsuda S, Ajima M (1999) A preliminary study of resprouting ability of some mangrove species after cutting. Tropics 8:221-224

Turner IM, Gong WK, Ong JE, Bujang JS, Kohyama T (1995) The architecture and allometry of mangrove saplings. Funct Ecol 9:205-212

Witkowski ETF, Lamont BB (1991) Leaf-specific mass confounds leaf density and thickness. Oecologia 88:486-493

Wolanski E, Mazda Y, Ridd P (1992) Mangrove hydrodynamics. In: Robertson AI, Alongi DM (eds) Tropical mangrove ecosystems. American Geophysical Union, Washington, DC, p 43-62

Woodroffe C (1992). Mangrove sediments and geomorphology. In: Robertson AI, Alongi DM (eds) Tropical mangrove ecosystems. American Geophysical Union, Washington, DC, p 7-42

Submitted: November 6, 2007; Accepted: November 25, 2008 Proofs received from author(s): February 20, 2009 